\title{
Semen and Reproductive Parameters During Some Abstinence Periods After Cigarette Smoke Exposure in Male Rats
}

\author{
Michele Kimie Sankako*, Patricia Carvalho Garcia, Renata Carolina Piffer and Oduvaldo \\ Câmara Marques Pereira \\ Departamento de Farmacologia; Instituto de Biociências; Universidade Estadual Paulista; 18618-970; \\ Botucatu - SP - Brasil
}

\begin{abstract}
Cigarette smoking is very widespread globally and can also be implicated in male and female infertility. This study aimed to evaluate the testicular function throughout a complete spermatic cycle during abstinence from cigarette smoke exposure in order to identify a possible residual damage and whether the parameters could recover spontaneously. Male Wistar rats were randomly divided into control and cigarette smoke-exposed (20 cigarettes/day/2 months) groups. After finishing the treatment, according to the number of days after the last cigarette exposure (0, 15, 30, or 60 days), the rats were euthanized and analyzed for compromised sperm count and quality. Results showed residual damage on sperm concentration, motility and morphology; the recovery of these parameters occurred only at $60^{\text {th }}$ days of abstinence. The study showed that cigarette smoke exposure damaged the semen and reproductive parameters and that the spontaneous recovery of some parameters occurred only after a complete spermatic cycle subsequent to stopping smoke exposure.
\end{abstract}

Key words: Cigarette, Semen, Spermatozoa, Testicular Function, Male Rat

\section{INTRODUCTION}

Infertility is defined as the absence of conception after at least 12 months of unprotected intercourse in the couples with regular sex life (Zhu et al. 2009). Infertility affects up to $15 \%$ of the sexually active population and $30 \%$ of these cases are caused by the male factor (Brugo-Olmedo et al. 2001). It is important to consider that infertility can cause emotional disorders, including stress, low self-esteem and social isolation (Burns 2007). Such disorders result from the inability of these couples to generate offspring so important to complete their life project.

Recent years have indicated a decline in human sperm concentration and quality (Carlsen et al.
1992) associated with the environmental and lifestyle factors (Sharpe 2000). In this sense, the available biological, experimental and epidemiological data indicate that up to $13 \%$ of human infertility may be attributable to cigarette smoking (ASRM Practice Committee 2006). Cigarette smoke contains a large number of substances, including nicotine, carbon monoxide and recognized carcinogens and mutagens (Stedman 1968). Some of these substances and/or their metabolites can be detected in the seminal plasma (Hassan et al. 2008). This indicates the passage of these substances through the bloodtestis barrier. Cigarette can damage the sperm function and even the genetic material. Investigations have also found that cigarette

*Author for correspondence: michelesankako@gmail.com 
smoking decreases sperm motility (Sofikitis et al. 1995), increases abnormal sperm morphology (Sofikitis et al. 1995; Künzle et al. 2003) and decreases sperm concentration (Künzle et al. 2003). The sperm cells have low capacity for DNA repair while the paternal transmission of genotoxic damage is high (Zenzes et al. 1999). As a result increased risks for birth defects and childhood cancer can be observed in the offspring (Sorahan et al. 1997). In addition, the smoke depresses the antioxidant levels (Colagar et al. 2009), causing hormonal changes (Trummer et al. 2002) and the formation of toxic metabolites. Moreover, people exposed passively to cigarette smoking may suffer reproductive consequences similar to active smokers (ASRM Practice Committee 2006). In this aspect, the exact molecular mechanisms involved are not understood, but oxidative stress is suggested (Ozyurt et al. 2006).

Smokers who undergo infertility treatment are often advised to break the smoking habit (Künzle et al. 2003). In this case, the patients live through an abstinence period that is characterized by the psychological, biological and social symptoms such as a depressed or dysphoric mood, irritability, frustration or anger, anxiety, difficulty in concentrating and maintaining attention, decreased heart rate, increased appetite, weight gain, motor incoordination and tremors, increased susceptibility to viral infections and relationship problems (Rosas and Baptista 2002; Guerra 2004). During this period, changes or mutations in germ cell/sperm formation that may have occurred during cigarette smoking exposure can persist and compromise the fertilizing capacity and/or the generation of healthy offspring.

On the basis of these considerations, this study aimed to evaluate the testicular function (semen and reproductive parameters) in an animal model throughout a complete spermatic cycle during abstinence from cigarette smoke exposure in order to identify possible residual damage and whether these parameters could recover spontaneously.

\section{MATERIALS AND METHODS}

\section{Animals}

Wistar male rats (Rattus norvegiccus albinus) were obtained from the Central Animal House of University Estadual Paulista (UNESP, Botucatu, Brazil) and maintained under the standard conditions (temperature $25 \pm 1^{\circ} \mathrm{C}$, humidity $55 \pm 5 \%$ and lights on from 06:00 to 18:00 h) in accordance with the Ethical Principles in Animals Research adopted by the Brazilian College of Animal Experimentation. All the procedures were approved by the Institute of Biosciences/ UNESP Committee for Animal Research (protocol no. 26/07). For each set of experiments, one male sibling was chosen from each litter in order to decrease the litter effects.

\section{Experimental groups}

Thirty-two rats (60 days old) were divided into two groups: non-smoking control group and smoking group. The smoking group was exposed to cigarette smoke at a rate of 20 cigarettes per day for two months. After finishing the treatment, each group was subdivided into four subgroups $(0,15$, 30 and 60 days of abstinence from cigarette smoke exposure).

\section{Exposure to cigarette smoke}

Cigarette smoke exposure was conducted by the mainstream smoke generated by a mechanical smoking device and delivered into a chamber (De Souza et al. 2010). Smoke was released at a rate of 10 cigarettes per 30 minutes, twice in the morning with 10-minute rest intervals. This procedure was performed daily for 60 consecutive days. This period included a complete spermatogenic cycle, which is about 52 days (França et al. 1998). According to the manufacturer, each cigarette used in the experiment provided $10 \mathrm{mg}$ of tar, $0.7 \mathrm{mg}$ of nicotine, and $10 \mathrm{mg}$ of carbon monoxide.

Body weight and wet weights of right testis, epididymis and seminal vesicle

After finishing the treatment according to the number of days after the last exposure to cigarette smoke $(0,15,30$ or 60 days), the rats were weighed and anaesthetized with sodium pentobarbital $(40 \mathrm{mg} / \mathrm{Kg}$, ip.). The right testis, epididymis and seminal vesicle were identified, removed and their weights (absolute and relative to body weights) were determined. The seminal secretion (difference between the seminal vesicle weight with and without secretion) was also determined.

\section{Sperm quality}

All the spermatozoa present in the vas deferens were collected and diluted in $1.0 \mathrm{~mL}$ of culture medium (Ham Nutrient F-10 Modify; Cultilab, Campinas, Brazil) for the evaluation of sperm 
concentration (luminal sperm content in the vas deferens), motility, vitality, and morphology. Sperm concentration and motility were analyzed in a Makler counting chamber (Sefi-Medical, Haifa, Israel). Sperm motility was assessed by counting both the motile and immotile spermatozoa in at least 10 separate randomly selected fields. At least 100 spermatozoa were evaluated per $10-\mu \mathrm{L}$ drop in the five drops analyzed from each sample under a bright-field microscope (magnification $\times 125$ ). Then, the proportion of spermatozoa that exhibited flagellar activity was recorded. Sperm vitality was analyzed after staining with eosin Y-nigrosin. One hundred spermatozoa were evaluated using phase contrast microscopy at $\times 400$ and were classified as either dead (if they were orange-red in color, indicating that the stain had passed through the membrane) or alive (if they were not stained). Results are expressed as the percentage of live sperm. This staining technique made it possible to differentiate the spermatozoa that were immotile but alive from those that were dead. A reduction in the percentage of motile spermatozoa associated with a high percentage of viable spermatozoa might reflect the structural or metabolic abnormalities that were derived from the abnormalities in testicular function or antimotility factors in the seminal plasma (WHO 1999). To evaluate the sperm morphology, smears were prepared on histological slides, stained with hematoxylin and Shorr and observed under a phase contrast microscope (magnification $\times 1000$ ). Spermatozoa were classified as normal or abnormal (Seed et al. 1996; WHO 1999).

\section{Daily Sperm Production and sperm number}

Homogenization-resistant testicular spermatids (stage 19 of spermiogenesis) were counted as described by Robb et al. (1978), with some modifications (Fernandes et al. 2007). Briefly, the right testis was decapsulated and weighed soon after the collection and homogenized in $5.0 \mathrm{~mL}$ of $0.9 \% \mathrm{NaCl}$ containing $0.5 \%$ Triton $\mathrm{X}-100$, followed by sonication for $30 \mathrm{~s}$. After a 10 -fold dilution, a sample was transferred to Neubauer chambers (four fields per animal) and the number of mature spermatids was counted. Daily sperm production (DSP) was determined by dividing the total number of homogenization-resistant spermatids per testis by 6.1 , which is the number of days of the seminiferous cycle during which these spermatids are present in the seminiferous epithelium.

\section{Statistics}

For normally distributed data, results were analyzed by descriptive statistics. Then, Student's t-test and the Mann-Whitney U-test were used, with results considered significant at $\mathrm{P}<0.05$.

\section{RESULTS}

The analysis in Table 1 showed significant reductions in the percentages of progressive motile spermatozoa and morphologically normal spermatozoa in the rats exposed to cigarette smoke compared to control rats at 0,15 and 30 days of abstinence. However, at day 60 , this change was not observed, indicating a possible recovery of these parameters. The vitality was not altered at any of the four observation moments. The rats exposed to cigarette smoke also showed reduction in sperm concentration compared to the control rats at 0,15 and 30 days of abstinence (Fig. 1). The numbers of spermatids per testis and DSP were significantly reduced in the rats exposed to cigarette smoke in relation to control rats, in all periods (Table 1).

As indicated in Table 2, body weight loss was observed in the cigarette-smoke exposure group at the first analyzed period. However, a weight gain was observed in the cigarette-smoke exposure group at 60 days of cigarette abstinence.

The absolute and relative wet weights of seminal vesicle and seminal vesicle secretion at the first period analyzed were increased in cigarette-smoke exposure group (Table 2). On the other hand, the relative seminal vesicle, testis and epididymis weights were decreased in smoke-exposed group at 30 and 60 days of cigarette abstinence (Table 2 and 3). 
Table 1 - Sperm quality from vas deferens and sperm count in control and cigarette-smoke-exposed rats.

\begin{tabular}{|c|c|c|c|c|c|c|}
\hline $\begin{array}{c}\text { Days of } \\
\text { cigarette-smoke } \\
\text { abstinence }\end{array}$ & Groups & $\begin{array}{c}\text { Progressive } \\
\text { motility } \\
(\%)\end{array}$ & $\begin{array}{l}\text { Morphology } \\
\text { (\% normal } \\
\text { spermatozoa) }\end{array}$ & $\begin{array}{c}\text { Vitality } \\
\text { (\% live } \\
\text { spermatozoa) }\end{array}$ & $\begin{array}{c}\text { No. } \\
\text { spermatids } \\
\text { (x 10 } \text { 10 }^{6} \text { per testis) }\end{array}$ & $\begin{array}{l}\text { DSP } \\
\text { (no. spermatids } x \\
10^{6} \text { per rat per day) }\end{array}$ \\
\hline \multirow[b]{2}{*}{ Zero } & $\begin{array}{c}\text { Control } \\
(\mathrm{n}=4)\end{array}$ & $\begin{array}{c}53.50 \\
(5200-5525)\end{array}$ & $\begin{array}{c}98.00 \\
(9775-9800)\end{array}$ & $\begin{array}{c}99.00 \\
(98-99-90)\end{array}$ & $412.99 \pm 25.64$ & $67.70 \pm 4.20$ \\
\hline & $\begin{array}{c}\text { Cigarette } \\
(\mathrm{n}=4)\end{array}$ & $\begin{array}{c}27.50^{\#} \\
(26.75-28.50)\end{array}$ & $\begin{array}{c}94.50^{\#} \\
(93.75-95.50)\end{array}$ & $\begin{array}{c}98.00 \\
(98.00-98.25)\end{array}$ & $244.34 \pm 2.19 *$ & $45.07 \pm 0.36 *$ \\
\hline \multirow{2}{*}{$15^{\text {th }}$} & $\begin{array}{c}\text { Control } \\
(\mathrm{n}=4)\end{array}$ & $\begin{array}{c}66.50 \\
(65.50-67.50)\end{array}$ & $\begin{array}{c}98.50 \\
(97.75-99.00)\end{array}$ & $\begin{array}{c}99.00 \\
(99.00-99.25)\end{array}$ & $382.41 \pm 15.52$ & $62.69 \pm 2.55$ \\
\hline & $\begin{array}{c}\text { Cigarette } \\
(\mathrm{n}=4)\end{array}$ & $\begin{array}{c}47.00^{\#} \\
(45.50-48.00)\end{array}$ & $\begin{array}{c}96.00^{\#} \\
(95.75-96.00)\end{array}$ & $\begin{array}{c}98.00 \\
(97.75-98.25)\end{array}$ & $244.34 \pm 5.19 *$ & $40.06 \pm 0.85^{*}$ \\
\hline \multirow{2}{*}{$30^{\text {th }}$} & $\begin{array}{c}\text { Control } \\
(n=4)\end{array}$ & $\begin{array}{c}52.00 \\
(49.75-56.25)\end{array}$ & $\begin{array}{c}98.00 \\
(97.75-98.00)\end{array}$ & $\begin{array}{c}99.00 \\
(98.75-99.25)\end{array}$ & $477.90 \pm 38.85$ & $78.34 \pm 6.37$ \\
\hline & $\begin{array}{c}\text { Cigarette } \\
(\mathrm{n}=4)\end{array}$ & $\begin{array}{c}35.00^{\#} \\
(35.25-36.50)\end{array}$ & $\begin{array}{c}96.00^{\#} \\
(95.75-96.25)\end{array}$ & $\begin{array}{c}98.00 \\
(97.75-98.25)\end{array}$ & $263.29 \pm 6.43 *$ & $43.16 \pm 1.05^{*}$ \\
\hline \multirow{2}{*}{$60^{\text {th }}$} & $\begin{array}{l}\text { Control } \\
(\mathrm{n}=4)\end{array}$ & $\begin{array}{c}52.50 \\
(50.00-55.50)\end{array}$ & $\begin{array}{c}97.50 \\
(96.50-98.25)\end{array}$ & $\begin{array}{c}98.00 \\
(98.00-98.25)\end{array}$ & $83.44 \pm 3.93$ & 0.65 \\
\hline & $\begin{array}{c}\text { Cigarette } \\
(\mathrm{n}=4)\end{array}$ & $\begin{array}{c}52.50 \\
(45.00-56.75)\end{array}$ & $\begin{array}{c}96.00 \\
(95.75-96.25)\end{array}$ & $\begin{array}{c}98.00 \\
(98.00-98.25)\end{array}$ & $236.67 \pm 5.71^{*}$ & $38.80 \pm 0.94 *$ \\
\hline
\end{tabular}

Values expressed as median (IQ25\% - IQ75\%) or as mean \pm S.E.M.

${ }^{\#} \mathrm{p}<0.05$ by Mann-Whitney U-test.* $\mathrm{p}<0.05$ by Student's t-test.

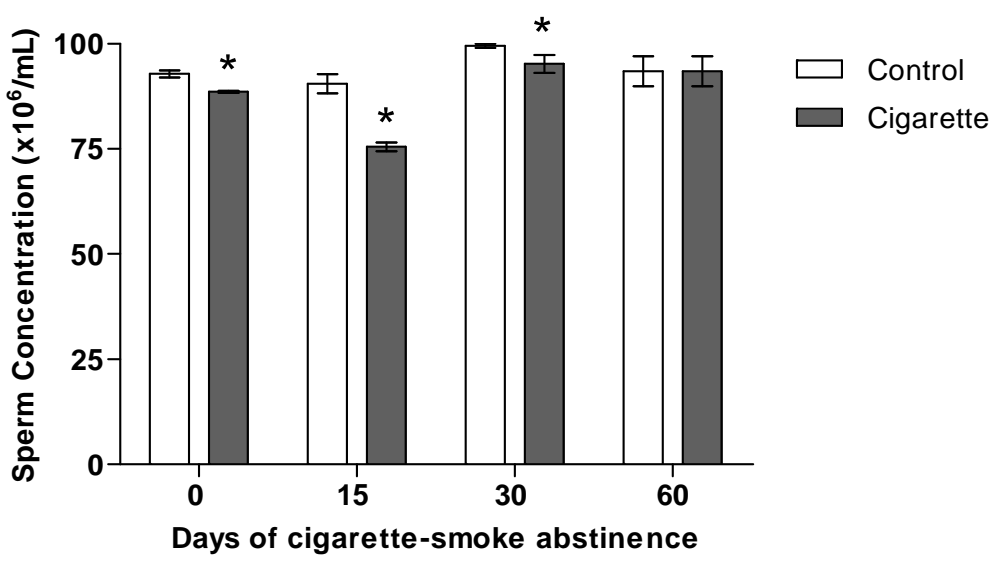

Figure 1 - Sperm concentration of control and cigarette-smoke exposed rats. Values expressed as mean \pm S.E.M. of 4 animals/group in each period of cigarette-smoke abstinence; $* \mathrm{p}<0.05$ by Student's t-test.

Table 2 - Body weight, absolute and relative (/100g of body weight) wet weights of seminal vesicle and seminal vesicle secretion in control and cigarette-smoke-exposed rats.

\begin{tabular}{cccccc}
$\begin{array}{c}\text { Days of cigarette- } \\
\text { smoke abstinence }\end{array}$ & Groups & $\begin{array}{c}\text { Body } \\
\text { weight }(\mathbf{g})\end{array}$ & $\begin{array}{c}\text { Seminal vesicle } \\
\text { weight }(\mathbf{m g})\end{array}$ & $\begin{array}{c}\text { Seminal vesicle } \\
\text { weight }(\mathbf{m g} / \mathbf{1 0 0 g})\end{array}$ & $\begin{array}{c}\text { Seminal vesicle } \\
\text { secretion weight }(\mathbf{m g})\end{array}$ \\
\hline \multirow{2}{*}{ Zero } & Control $(\mathrm{n}=4)$ & $474.69 \pm 9.93$ & $347.75 \pm 16.48$ & $73.26 \pm 3.47$ & $368.97 \pm 13.77$ \\
& Cigarette $(\mathrm{n}=4)$ & $431.93 \pm 11.38^{*}$ & $415.23 \pm 21.82^{*}$ & $96.13 \pm 5.05^{*}$ & $500.09 \pm 15.98^{*}$ \\
\hline \multirow{2}{*}{$15^{\text {th }}$} & Control $(\mathrm{n}=4)$ & $558.46 \pm 18.22$ & $334.95 \pm 6.57$ & $60.21 \pm 5.26$ & $512.93 \pm 17.35$ \\
& Cigarette $(\mathrm{n}=4)$ & $527.56 \pm 24.77$ & $335.23 \pm 16.26$ & $63.91 \pm 3.80$ & $536.47 \pm 22.75$ \\
\hline \multirow{2}{*}{$30^{\text {th }}$} & Control $(\mathrm{n}=4)$ & $488.08 \pm 23.14$ & $327.25 \pm 8.63$ & $67.37 \pm 2.74$ & $469.27 \pm 26.05$ \\
& Cigarette $(\mathrm{n}=4)$ & $545.34 \pm 24.65$ & $295.43 \pm 9.55$ & $54.71 \pm 3.96^{*}$ & $481.89 \pm 15.15$ \\
\hline \multirow{2}{*}{$60^{\text {th }}$} & Control $(\mathrm{n}=4)$ & $498.29 \pm 27.06$ & $243.73 \pm 12.61$ & $50.99 \pm 1.57$ & $514.92 \pm 33.66$ \\
& Cigarette $(\mathrm{n}=4)$ & $664.53 \pm 25.40^{*}$ & $277.95 \pm 12.54$ & $41.80 \pm 0.60^{*}$ & $546.51 \pm 29.45$ \\
\hline
\end{tabular}

Values expressed as mean \pm S.E.M.; $* \mathrm{p}<0.05$ by Student's t-test. 
Table 3 - Absolute and relative (/100g of body weight) wet weights of testis and epididymis in control and cigarettesmoke-exposed rats.

\begin{tabular}{clcccc}
\hline $\begin{array}{c}\text { Days of cigarette } \\
\text {-smoke abstinence }\end{array}$ & \multicolumn{1}{c}{ Groups } & $\begin{array}{c}\text { Testis } \\
\text { weight }(\mathbf{g})\end{array}$ & $\begin{array}{c}\text { Testis weight } \\
(\mathbf{g} / \mathbf{1 0 0 g})\end{array}$ & $\begin{array}{c}\text { Epididymis } \\
\text { weight }(\mathbf{g})\end{array}$ & $\begin{array}{c}\text { Epididymis } \\
\text { weight }(\mathbf{g} / \mathbf{1 0 0 g})\end{array}$ \\
\hline \multirow{2}{*}{ Zero } & Control $(\mathrm{n}=4)$ & $1.76 \pm 0.02$ & $0.37 \pm 0.01$ & $0.81 \pm 0.01$ & $0.17 \pm 0.01$ \\
& Cigarette $(\mathrm{n}=4)$ & $1.74 \pm 0.10$ & $0.40 \pm 0.02$ & $0.77 \pm 0.02$ & $0.17 \pm 0.01$ \\
\hline \multirow{2}{*}{$15^{\text {th }}$} & Control $(\mathrm{n}=4)$ & $1.88 \pm 0.04$ & $0.34 \pm 0.02$ & $0.74 \pm 0.01$ & $0.13 \pm 0.01$ \\
& Cigarette $(\mathrm{n}=4)$ & $1.83 \pm 0.02$ & $0.35 \pm 0.02$ & $0.73 \pm 0.01$ & $0.14 \pm 0.01$ \\
\hline \multirow{2}{*}{$30^{\text {th }}$} & Control $(\mathrm{n}=4)$ & $2.04 \pm 0.09$ & $0.42 \pm 0.02$ & $0.80 \pm 0.04$ & $0.16 \pm 0.01$ \\
& Cigarette $(\mathrm{n}=4)$ & $1.82 \pm 0.06$ & $0.34 \pm 0.02^{*}$ & $0.74 \pm 0.02$ & $0.14 \pm 0.01^{*}$ \\
\hline \multirow{2}{*}{$60^{\text {th }}$} & Control $(\mathrm{n}=4)$ & $1.84 \pm 0.05$ & $0.37 \pm 0.01$ & $0.71 \pm 0.02$ & $0.15 \pm 0.01$ \\
& Cigarette $(\mathrm{n}=4)$ & $1.85 \pm 0.02$ & $0.28 \pm 0.01^{*}$ & $0.73 \pm 0.02$ & $0.11 \pm 0.01^{*}$ \\
\hline
\end{tabular}

Values expressed as mean \pm S.E.M.; * $\mathrm{p}<0.05$ by Student's t-test.

\section{DISCUSSION}

Smoking is considered a lifestyle hazard to both active and passive smokers. Cigarette smoking may also be related to subfertility or infertility. There is a particular interest in the environmental and lifestyle factors implicated in subfertility and infertility because, unlike genetic causes, curative or preventive measures can be implemented in this treatment. It is important to consider that prospective fathers not only should abstain from smoking, but also avoid exposure to second-hand smoke (Polyzos et al. 2009). The present study confirmed that cigarette-smoke exposure, in fact, harmed semen and reproductive parameters. Furthermore, residual damages were observed even during abstinence from cigarette-smoke exposure.

Sperm parameters can provide valuable information regarding potential reproductive toxicity (Seed et al. 1996). In human smokers, there are reports that cigarette smoking can reduce sperm concentration (Künzle et al. 2003; Liu et al. 2010), percentage of motile (Sofikitis et al. 1995; Kumosani et al. 2008; Liu et al. 2010) and normal sperm morphology (Sofikitis et al. 1995; Künzle et al. 2003; Liu et al. 2010). In the rats, Yamamoto et al. (1998) and Kapawa et al. (2004) observed that long-term exposure to cigarette smoke provoked reductions in sperm concentration and/or motility. The potential correlation between the semen parameters and an agent that alters male reproductive function is greater in humans than in animals. Therefore, it is prudent to assume that many perturbations of reproductive function that will not affect birth rate in a population of infrahuman mammals could cause reproductive failure in humans (Amann 1986).

Corroborating with some of the cited investigations, the present study showed decreases in sperm concentration and in percentages of motile and morphologically normal sperm in the rats from cigarette-smoke exposure group. Furthermore, the residual damage induced by cigarette smoke was shown by these alterations in 15 days and 30 days of abstinence from cigarettesmoke exposure. In addition, spontaneous recovery of these parameters was demonstrated at 60 days of abstinence.

Spermatogenesis occurs in the testis and its duration varies among species, for example, about 52 days in the rats (França et al. 1998) and 64 days in the humans (Heller and Clermont 1963). In the present study, the daily sperm production (DSP) and number of testicular spermatids were reduced in the groups exposed to cigarette smoke in all the periods observed. These alterations were corroborated by some other studies that demonstrated harmful effects of cigarette smoke on spermatogenesis in male rats. The rats exposed to cigarette smoke showed a reduction in the seminiferous tubule diameter (Rajpurkar et al. 2000; Ahmadnia et al. 2007), decreased germ cell count (Rajpurkar et al. 2000), fewer Sertoli cells (Ahmadnia et al. 2007), degeneration of the Leydig cells, and a decrease in its population (Yardimci et al. 1997). The absence of spontaneous recovery of DSP and number of testicular spermatids occurred probably because cigarette smoke caused direct effect on male germ cells (Robbins et al. 2005) and needed more time to restore. In addition, seminal parameters could 
be normal prior to DSP recovery since in the seminal fluid, a natural storage of sperm occurred before the release of this fluid. Cigarette smoke is a complex milieu possessing an array of free radicals and reactive oxygen species (ROS) that promote lipid peroxidation and consequently perturb the antioxidant defense system in the blood and tissues of smokers (Pryor 1997; Delibas et al. 2003). Thus, one possible mechanism by which exposure to cigarette smoke leads to damage in seminal and reproductive parameters is oxidative stress (Ozyurt et al. 2006).

In the present study the absolute wet weights of the testis and epididymis did not show alteration at any abstinence analyzed moment. On the other hand, the absolute and relative wet weights of seminal vesicle and seminal vesicle secretion at the first period analyzed were increased in cigarette-smoke exposure group. These data showed an accumulation of secretion in the seminal vesicles of this group by cigarette smoke exposure, probably due to deficiency of seminal vesicle's contraction. This contraction deficiency could be related to low testosterone level in cigarette smoke exposed rats (Garcia et al. 2012), since seminal vesicle's contraction depend on appropriated testosterone level (Pereira et al. 2003; Pereira and Piffer 2005).

It is well documented that cigarette smoking can decrease weight and some people, mainly adolescents, smoke and try to lose weight with this habit (Johnson et al. 2009). Consequently, during abstinence from cigarette smoking, individuals go through several changes including increased appetite and weight gain (Rosas and Baptista 2002; Guerra 2004). In the present study, using the rats as animal model, a body weight loss was observed in cigarette-smoke exposure group at the first period analyzed. In addition, a body weight gain was also observed in cigarette-smoke exposure group at 60 days of cigarette abstinence. These alterations could be due to metabolic effects of nicotine (Nerín et al. 2007). Bellinger et al. (2010) showed that the administration of nicotine to the rats induced a decrease in body weight that was not the result of increasing metabolic rate but by causing a reduction in food intake. The exact mechanism that nicotine affects feeding behavior need to be elucidated. However, there are some suggestions. Neuropeptides such as neuropeptide Y (Bishop et al. 2002) and peptides hormones such as leptin (Klein et al. 2004) could be involved in feeding-related actions of nicotine. Neuropeptide
$\mathrm{Y}$ is a potent stimulator of feeding and could be decreased by nicotine. In contrast, leptin is a negative regulator of food intake hormone, that acts as a signaling molecule and communicates the level of body fat reserves to the hypothalamus, could be increased by nicotine. In addition, nicotine can also increase the release of neurotransmitters, including dopamine and serotonine, which are inhibitors food intake (Yang et al. 1999). The reductions of relative wet weights of testis, epididymis and seminal vesicle at 30 and 60 days of abstinence in smoke-exposed groups probably occurred due to the increase of body weight of these groups.

Thus, the results of the present study confirmed that cigarette smoke exposure damaged the semen as well as reproductive parameters. The exact mechanism by which cigarette smoke caused these effects on male reproduction needs to be elucidated. However, the spontaneous recovery of some parameters such as sperm concentration, percentages of motile and morphologically normal sperm occurred during a complete spermatic cycle, following the cessation of this exposure. Thus, it will be interesting to investigate whether an equivalent abstinence period in the humans would minimize the residual damages caused by cigarette smoking and thereby improve the treatment of smoker's infertility.

\section{ACKNOWLEDGMENTS}

This study was supported financially by fellowships from Conselho Nacional de Desenvolvimento Científico e Tecnológico $(\mathrm{CNPq})$.

\section{REFERENCES}

Ahmadnia H, Ghanbari M, Moradi MR, Khaje-Dalouee M. Effect of cigarette smoke on spermatogenesis in rats. Urol J. 2007; 4: 159-163.

Amann RP. Detection of alterations in testicular and epididymal function in laboratory animals. Environ Health Perspect. 1986; 70: 149-158.

Bellinger LL, Wellman PJ, Harris RBS, Kelso EW, Kramer PR. The effects of chronic nicotine on meal patterns, food intake, metabolism and body weight of male rats. Pharmacol Biochem Behav. 2010; 95: 9299.

Bishop C, Parker GC, Coscina DV. Nicotine and its withdrawal after feeding induced by paraventricular hypothalamic injections of neuropeptide $\mathrm{Y}$ in 
Sprague-Dawley rats. Psychopharmacology. 2002; 162: 265-272.

Brugo-Olmedo S, Chillik C, Kopelman S. Definition and causes of infertility. Reprod Biomed Online. 2001; 2: 41-53.

Burns LH. Psychiatric aspects of infertility and infertility treatments. Psychiatr Clin North Am. 2007; 30: 689-716.

Carlsen E, Giwercman A, Keiding N, Skakkebaek NE. Evidence for decreasing quality of semen during past 50 years. BMJ. 1992; 305: 609-613.

Colagar AH, Marzony ET, Chaichi MJ. Zinc levels in seminal plasma are associated with sperm quality in fertile and infertile men. Nutr Res. 2009; 29: 82-88.

Delibas N, Ozcankaya R, Altuntas I, Sutcu R. Effect of cigarette smoke on lipid peroxidation, antioxidant enzymes and NMDA receptor subunits $2 \mathrm{~A}$ and $2 \mathrm{~B}$ concentration in rat hippocampus. Cell Biochem Funct. 2003; 21: 69-73.

De Souza MSS, Sinzato YK, Lima PHO, Calderon, IMP, Rudge MVC, Damasceno DC. Oxidative stress status and lipid profiles of diabetic pregnant rats exposed to cigarette smoke. Reprod Biomed Online. 2010; 20: 547-552.

Fernandes GS, Arena AC, Fernandez CD, Mercadante A, Barbisan LF, Kempinas, WG. Reproductive effects in male rats exposed to diuron. Reprod Toxicol. 2007; 23: 106-112.

França LR, Ogawa T, Avarbock MR, Brinster RL, Russell LD. Germ cell genotype controls cell cycle during spermatogenesis in the rat. Biol Reprod. 1998; 59: 1371-1377.

Garcia PC, Piffer RC, Gerardin DCC, Sankako MK, Alves de Lima RO, Pereira OCM. Could zinc prevent reproductive alterations caused by cigarette smoke in male rats? Reprod Fertil Dev. 2012; 24: 559-567.

Guerra MP. A abstenção tabágica: Reflexões sobre a recaída. Aná Psicológica. 2004; 22: 507-518.

Hassan A, Abo-Azma SM, Fayed SM, Mostafa T. Seminal plasma cotinine and insulin-like growth factor-I in idiopathic oligoasthenoteratozoospermic smokers. BJU Int. 2008; 103: 108-111.

Heller CG, Clermont Y. Spermatogenesis in man: an estimate of its durations. Science. 1963; 140: 184186.

Johnson JL, Eaton DK, Pederson LL, Lowry R. Associations of trying to lose weight, weight control behaviors, and current cigarette use among US high school students. J Sch Health. 2009; 79: 355-360.

Kapawa A, Giannakis D, Tsoukanelis K, Kanakas N, Baltogiannis D, Agapitos E, et al. Effects of paternal cigarette smoking on testicular function, sperm fertilizing capacity, embryonic development, and blastocyst capacity for implantation in rats. Andrologia. 2004; 36: 57-68.
Klein LC, Corwin EJ, Ceballos RM. Leptin, hunger, and body weight: influence of gender, tobacco smoking, and smoking abstinence. Addic Behav 2004; 29: 921-927.

Kumosani TA, Elshal MF, Al-Jonaid AA, Abduljabar HS. The influence of smoking on semen quality seminal microelements and $\mathrm{Ca}^{2+}$-ATPase activity among infertile and fertile men. Clin Biochem. 2008; 41: 1199-1203.

Künzle R, Mueller MD, Hänggi W, Birkhäuser MH, Drescher H, Bersinger NA. Semen quality of male smokers and nonsmokers in infertile couples. Fertil Steril. 2003; 79: 287-291.

Liu R-Z, Gao J-C, Zhang H-G, Wang R-X, Zhang Z-H, Liu X-Y. Seminal plasma zinc level may be associated with the effect of cigarette smoking on sperm parameters. J Int Med Res. 2010; 38: 923-928.

Nerín I, Beamonte A, Gargallo P, Jiménez-Muro A, Marqueta A. Weight gain and anxiety levels in recent ex-smokers. Arch Bronconeumol. 2007; 43: 9-15.

Ozyurt H, Pekmez H, Parlaktas BS, Kus I, Ozyurt B, Sarsilmaz M. Oxidative stress in testicular tissues of rats exposed to cigarette smoke and protective effects of caffeic acid phenethyl ester. Asian J Androl. 2006; 8: 189-193.

Pereira OCM, Yasuhara F, Arena AC. Cholinergic responses of seminal vesicles isolated from rats exposed perinatally to hydrocortisone. Pharmacol Res. 2003; 48: 91-95.

Pereira OCM, Piffer RC. Puberty installation and adrenergic response of seminal vesicle from rats exposed prenatally to hydrocortisone. Life Sci. 2005; 77: 1381-1390.

Polyzos A, Schmid TE, Piña-Guzmán B, QuintanillaVega B, Marchetti F. Differential sensitivity of male germ cells to mainstream and sidestream tobacco smoke in the mouse. Toxicol Appl Pharmacol. 2009; 237: 298-305.

Practice Committee of The American Society For Reproductive Medicine. Smoking and infertility. Fertil Steril. 2006; 86: S172-S177.

Pryor WA. Cigarette smoke radicals and the role of free radicals in chemical carcinogenicity. Environ Health Perspect. 1997; 105: 875-882.

Rajpurkar A, Li H, Dhabuwala CB. Morphometric analysis of rat testis following chronic exposure to cigarette smoke. J Environ Pathol Toxicol Oncol. 2000; 19: 363-368.

Robb GW, Amann RP, Killian GJ. Daily sperm production and epididymal sperm reserves of pubertal and adult rats. J Reprod Fertil. 1978; 54: 103-107.

Robbins WA, Elashoff DA, Xun L, Jia J, Li N, Wu G, et al. Effect of lifestyle exposures on sperm aneuploidy. Cytogenet Genome Res. 2005; 111: 371377. 
Rosas M, Baptista F. Desenvolvimento de estratégias de intervenção psicológica para a cessação tabágica. Aná Psicológica. 2002; 20: 45-56.

Seed J, Chapin RE, Clegg ED, Dostal LA, Foote RH, Hurtt ME, et al. Methods for assessing sperm motility, morphology, and counts in the rat, rabbit, and dog: a consensus report. Reprod Toxicol. 1996; 10: 237-244.

Sharpe RM. Lifestyle and environmental contribution to male infertility. Br Med Bull. 2000; 56: 630-642.

Sofikitis N, Miyagawa I, Dimitriatidis D, Zavos P, Sikka S, Hellstrom W. Effects of smoking on testicular function, semen quality and sperm fertilizing capacity. J Urol. 1995; 154: 1030-1034.

Sorahan TP, Lancashire RJ, Hulten MA, Peck IM, Stewart AM. Childhood cancer and parental use of tobacco. Deaths from 1953 to 1955. Br J Cancer. 1997; 75: 134-138.

Stedman RL. The chemical composition of tobacco and tobacco smoke. Chem Rev. 1968; 68: 153-207.

Trummer H, Habermann H, Haas J, Pummer K. The impact of cigarette smoking on human semen parameters and hormones. Hum Reprod. 2002; 17: 1554-1559.

World Health Organization. Laboratory manual for the examination of human semen and sperm-cervical mucus interaction. 4th ed. Cambridge: Cambridge University Press; 1999.
Yamamoto Y, Isoyama E, Sofikitis N, Miyagawa I. Effects of smoking on testicular function and fertilizing potential in rats. Urol Res. 1998; 26: 45-48.

Yang Z-J, Blaha V, Meguid MM, Oler A, Miyata G. Infusion of nicotine into the LHA enhances dopamine and 5-HT release and suppresses food intake. Pharmacol Biochem Behav. 1999; 64: 155-159.

Yardimci S, Atan A, Delibasi T, Sunguroglu K, Güven MC. Long-term effects of cigarette-smoke exposure on plasma testosterone, luteinizing hormone and follicle-stimulating hormone levels in male rats. $\mathrm{Br} \mathrm{J}$ Urol. 1997; 79: 66-69.

Zenzes MT, Bielecki R, Reed TE. Detection of benzo(a)pyrene diol epoxide-DNA adducts in sperm of men exposed to cigarette smoke. Fertil Steril. 1999; 72: 330-335.

Zhu JL, Basso O, Carsten O, Hvidtjorn D, Olsen J. Infertility, infertility treatment and psychomotor development: the Danish National Birth Cohort. Paediatr Perinat Epidemiol. 2009; 23: 98-106.

Received: October 21, 2011; Revised: January 18, 2012; Accepted: August 20, 2012. 